\title{
PENINGKATAN HASIL BELAJAR SISWA MENGGUNAKAN MODEL PEMBELAJARAN TWO STAY TWO STRAY PADA MATERI PENYELENGGARAAN KEKUASAAN NEGARA DI MAN 1 BANJARMASIN
}

\author{
Wasilah \\ MAN 1 Banjarmasin
}

\begin{abstract}
ABSTRAK
Penelitian ini bertujuan untuk meningkatkan hasil belajar melalui penerapan model two stay two stray pada materi penyelenggaraan kekuasaan negara di kelas XI MIA 1 MAN 1 Banjarmasin. Masalah yang dihadapi guru adalah hasil belajar siswa pada mata pelajaran PPKn yang relatif rendah, terutama materi penyelenggaraan kekuasaan negara masih di bawah KKM. Berdasarkan data hasil ulangan tengah semester diketahui di kelas XI MIA 1 nilai rata-rata kelas untuk mata pelajaran PPKn yaitu 60 masih di bawah KKM yang mengharuskan siswa mencapai ketuntasan yaitu 75 . Oleh sebab itu dilakukan penelitian tindakan kelas yang dilaksanakan sebanyak dua siklus tindakan: (1) perencanaan, (2) pelaksanaan, (3) observasi, dan (4) refleksi.

Hasil penelitian tindakan kelas ini menunjukkan terdapat peningkatan hasil belajar melalui penerapan model two stay two stray pada materi penyelenggaraan kekuasaan negara di kelas XI MIA 1 MAN 1 Banjarmasin tahun 2016/2017 dari 63,5 menjadi 74,71 (siklus I) dan 65,89 menjadi 78,82 (siklus II). Selain itu terdapat peningkatan aktivitas belajar melalui penerapan model two stay two stray pada materi penyelenggaraan kekuasaan negara di kelas XI MIA 1 MAN 1 Banjarmasin tahun 2016/2017 yaitu $0 \%$ menjadi $76 \%$ pada siklus I dan dari $0 \%$ menjadi $88 \%$ pada siklus II.
\end{abstract}

Kata kunci: hasil belajar; model two stay two stray; penyelenggaraan kekuasaan negara

\begin{abstract}
This study aimed to improve learning outcomes through the application of The Two Stay Two Stray model in State Power Management material at the class of XI MIA (Science Program) 1 in MAN 1 Banjarmasin. The teacher found out that student learning outcomes in study subject of Civics are relatively low, especially in the sub-matter of State Power Management which is still under minimum criteria of scoring standard. Based on the midterm test results, it was known that the students got the average grade for this subject is 60 , which is still below the standard that requires students to achieve 75 of scoring. Therefore, classroom action research is carried out in two action cycles: (1) planning, (2) implementation, (3) observation, and (4) reflection.

The results of this Class Action Research showed that there is an increase in learning outcomes through the application of the Two Stay Two Stray model in the material of State Power Management at the class of XI MIA (Science Program) 1 in MAN 1 Banjarmasin, academic year of 2016/2017 from 63.5 to 74.71 (cycle I) and 65.89 to 78.82 (cycle II). Furthermore, there was also an increase in learning activities through the learning model of Two Stay Two Stray application which was $0 \%$ to $76 \%$ in the first cycle and from $0 \%$ to $88 \%$ in the second cycle.
\end{abstract}

Keywords: learning outcomes; two stay two stray model; state power management 


\section{PENDAHULUAN}

Pembelajaran Pendidikan Pancasila dan Kewarganegaraan (PPKn) sebenarnya mempunyai peran yang sangat penting. Mata pelajaran PPKn diharapkan mampu membentuk siswa yang ideal, memiliki mental yang kuat, dan mampu bertahan dalam segala kondisi sehingga dapat mengatasi permasalahan yang akan dihadapi. Mata pelajaran PPKn merupakan mata pelajaran yang lebih aplikatif karena berhubungan langsung dengan kehidupan sehari-hari.

Dalam kegiatan pembelajaran PPKn siswa dituntut tidak hanya mampu mengingat dan menghapalkan teori-teori saja, namun mampu mengaplikasikannya dalam kehidupan sehari-hari sehingga lebih bermakna. Untuk mencapai pembelajaran PPKn yang bermakna diperlukan keaktifan siswa, sehingga siswa terlibat langsung dalam proses pembelajaran.

Guru sebagai pengajar atau pendidik merupakan salah satu faktor penentu keberhasilan proses belajar mengajar. Itulah sebabnya guru dituntut mampu mengatasi masalah-masalah dalam proses belajar mengajar. Guru harus mampu memilih strategi pembelajaran dengan tepat, sesuai, dan efesien untuk merangsang siswa aktif dan kreatif belajar. Guru harus mampu menciptakan kondisi belajar yang kondusif agar siswa merasa senang dan tidak bosan sehingga menambah interaksi dan keikut sertaan siswa dalam belajar.

Di kelas XI MIA 1 MAN 1 Banjarmasin selama ini siswanya masih kurang aktif dalam hal bertanya dan menjawab, siswa yang yang aktif hanya 30 $\%$, dan siswa yang mempunyai kemampuan menjawab hanya $25 \%$ saja. Kurang aktifnya siswa ternyata mempunyai pengaruh terhadap hasil belajarnya. Ini terbukti nilai rata-rata kelas untuk mata pelajaran PPKn yaitu 60 masih dibawah KKM yang mengharuskan siswa mencapai ketuntasan yaitu 75 . Ini suatu permasalahan yang harus segera dicarikan solusinya.

Memperhatikan permasalahan di atas, sudah selayaknya dalam pengajaran PPKn dilakukan suatu inovasi. Diperlukan suatu model pembelajaran yang dapat meningkatkan aktivitas siswa. Peneliti mencoba untuk menggunakan sebuah model yang merupakan pengembangan dari model-model pembelajaran kooperatif yaitu model pembelajaran Two Stay Two Stray. Dengan model pembelajaran ini diharapkan siswa dapat lebih aktif dalam pembelajaran sehingga mendaptkan hasil belajar yang mampu mencapai KKM bahkan lebih tinggi dari KKM. Berdasarkan uraian di atas, maka penelitian ini mengambil judul "Peningkatan Hasil Belajar Menggunakan Model Two Stay Two Stray pada Materi Penyelenggaraan Kekuasaan Negara di MAN 1 Banjarmasin".

Tujuan yang ingin dicapai pada penelitian ini adalah untuk mendeskripsikan sebagai berikut:

1. Peningkatan hasil belajar melalui penerapan model two stay two stray pada materi penyelenggaraan kekuasaan negara di Kelas XI MIA 1 MAN 1 Banjarmasin tahun pelajaran 2016/2017

2. Peningkatan aktivitas belajar melalui penerapan model two stay two stray pada materi penyelenggaraan kekuasaan negara di kelas XI MIA 1 MAN 1 Banjarmasin tahun pelajaran 2016/2017.

\section{METODE}

Penelitian tindakan kelas adalah solusi atau mencari jalan keluar tentang situasi masalah yang terjadi. Menurut Sumadayo (2013), penelitian tindakan kelas adalah kajian tentang situasi sosial dengan maksud untuk meningkatkan kualitas kegiatan yang ada di dalamnya. Prosedur penelitian tindakan kelas ini meliputi: planning (perencanaan), acting (pelaksanaan), observating (pengamatan), 
dan reflecting (refleksi).

Tahap pelaksanaan observasi siklus I pada tanggal 5 April 2017, pertemuan 2 tanggal 12 April 2017, pertemuan 1 siklus II tanggal 9 Mei 2017 dan pertemuan 2 pada tanggal 16 Mei 2017.Penelitian ini dilakukan di kelas XI MIA 1 MAN 1 Banjarmasin yang beralamat Kampung Melayu Darat Banjarmasin Tengah, Kota Banjarmasin, Kalimantan Selatan. Subjek amatan siswa kelas XI MIA 1 MAN 1 Banjarmasin tahun 2016/2017.

Jumlah siswa kelas ini ada 33 orang, tetapi yang terlibat dalam penelitian ini hanya 17 orang karena belum tercapai KKM 75 pada saat pelaksanaan ulangan semester khususnya pada materi penyelenggaraan kekuasaan negara. Kelas XI MIA 1 di MAN 1 Banjarmasin mempunyai kemampuan siswa bervariasi, terdiri dari siswa yang berkemampuan sangat tinggi, tinggi, sedang dan kurang. Kemampuan ini tentu saja mempengaruhi gaya belajar siswa dalam proses belajar mengajar.

Waktu dari perencanaan sampai penulisan laporan dapat dilihat pada tabel 1.
2. Siswa berkerjasama dalam kelompok untuk menyelesaikan tugas -tugas tersebut.

3. Setelah waktu yang telah ditentukan, dua orang dari masing-masing kelompok menjadi tamu kekelompok masing-masing kelompok manjadi tamu kelompok yang lain (stay) untuk mencari informasi yang lain.

4. Dua orang yang tinggal dalam kelompok (stay) bertugas membagikan hasil kerja dan informasi pada tamu mereka.

5. Setelah semua tamu selesai dari kegiatan bertamunya, tamu kembali ke kelompok mereka sendiri dan melaporkan temuan mereka dari kelompok yang lain.

6. Masing-masing kelompok kembali bekerjasama mencocokkan dan membahas hasil kerja mereka.

\section{Prosedur Penelitian}

Metode penelitian berhubungan dengan tata urutan penelitian ini akan dilakukan. Karena penelitian ini adalah penelitian tindakan kelas maka metode penelitian yang digunakan adalah metode

Tabel 1. Jadwal Kegiatan

\begin{tabular}{|c|l|l|l|l|l|l|l|l|l|l|l|l|l|}
\hline \multirow{2}{*}{ No } & \multirow{2}{*}{ Kegiatan } & \multicolumn{8}{|c|}{ Minggu Kegiatan } \\
\cline { 2 - 13 } & & 1 & 2 & 3 & 4 & 1 & 2 & 3 & 4 & 1 & 2 & 3 & 4 \\
\hline 1 & Perencanaan & & & & & & & & & & & & \\
\hline 2 & Proses pembelajaran & & & & & & & & & & & & \\
\hline 3 & Proses pembelajaran & & & & & & & & & & & & \\
\hline 4 & Pengumpulan Data & & & & & & & & & & & & \\
\hline 5 & Analisis Data & & & & & & & & & & & & \\
\hline 6 & Penyusunan Hasil & & & & & & & & & & & & \\
\hline 7 & Pelaporan Hasil & & & & & & & & & & & & \\
\hline
\end{tabular}

Model pembelajaran Two Stay Two Stray dengan sintaks sebagai berikut:

1. Siswa dibagi dalam kelompok yang berjumlah 4 (empat) orang. Setiap kelompok diberi tugas yang berkaitan dengan materi pelajaran. deskriptif. Metode deskriptif adalah suatu metode dalam meneliti status sekelompok manusia, suatu objek dengan tujuan membuat deskripsi yang sistematis, dan akurat mengenai fakta-fakta, sifat-sifat 
serta hubungan antar fenomena yang diselidiki (Nazir dalam Asniah, 2013).

Penelitian tindakan kelas melalui 4 tahap yaitu: perencanaan, pelaksanaan tindakan, observasi, dan refleksi, yang dilaksanakan dalam dua siklus (tiap siklus dilakukan 2 kali tatap muka). Sebagai suatu siklus dapat digambarkan langkah-langkah PTK pada gambar 1. mempersiapkan materi dan merancang pembelajaran yang mengarah ke kooperatif Model Two Stay Two Stray, membuat kriteria kelompok heterogen (jenis kelamin, kemampuan serta agama) dan mempersiapkan instrumen observasi disertai cara penskoran.

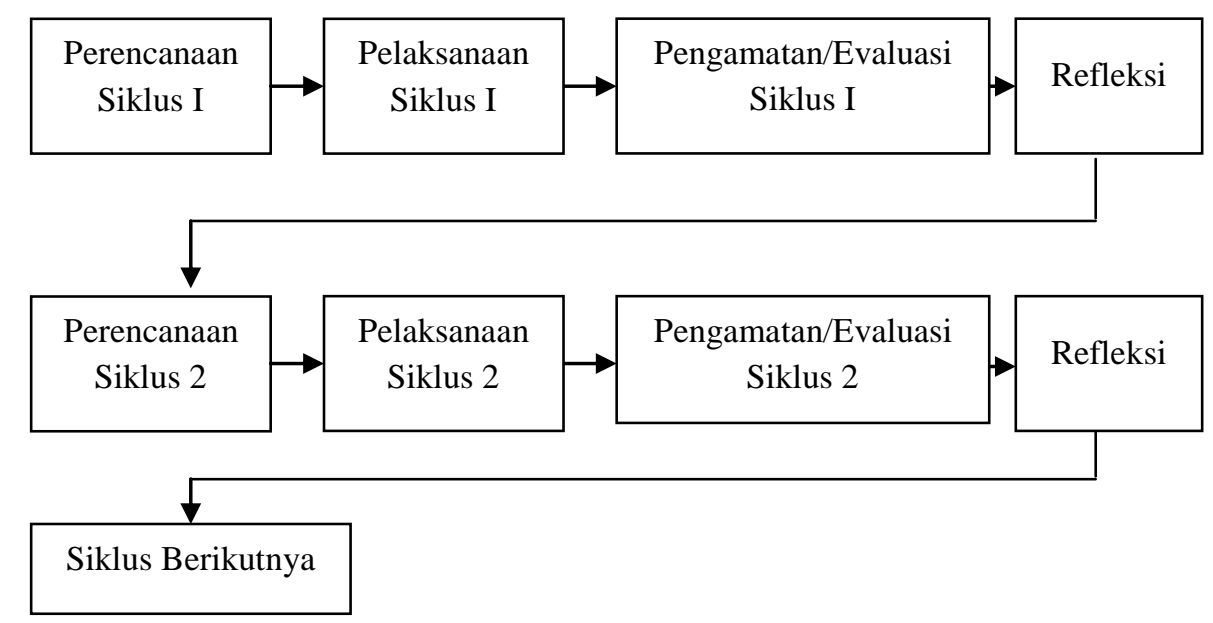

Gambar 1. Desain Langkah PTK (Arikunto, 2008).

Pada kegiatan siklus akan dilakukan sesuai dengan tahap-tahap tersebut.

1. Perencanaan

a. Peneliti melakukan analisis kurikulum untuk menentukan standar kompetensi dan kompetensi dasar yang akan disampaikan Kepada siswa dengan menggunakan pembelajaran kooperatif model Two Stay Two Stray

b. Membuat rencana pembelajaran kooperatif model Two Stay Two Stray dan lembar observasi.

c. Membuat Instrumen yang digunakan dalam siklus penelitian Tindakan kelas/alat Bantu/media yang diperlukan.

d. Membuat alat evaluasi

Secara garis besar tahapan pembelajaran kooperatif:

1) Tahap persiapan

Pada tahap ini, kegiatan yang dilakukan diantaranya
2) Tahap penyajian materi

Dalam tahap ini pengajar menyebutkan tujuan pembelajaran memotivasi rasa ingin tahu, memberikan apersepsi, umpan balik sesering mungkin, penjelasan yang tepat agar tidak terjadi miskonsepsi ,dan beralih pada konsep lain, jika siswa telah memahami pokok masalah.

3) Tahap kegiatan kelompok

Selanjutnya masing-masing kelompok membahas materi yang dibagikan, siswa mempelajari konsep-konsep materi PPKn penyelenggaraan kekuasaan negara dan mempresentasikan di depan kelas juga digunakan untuk melatih keterampilan kooperatif siswa dalam masing-masing kelompok. Jika salah satu siswa belum memahami materi, maka teman sekelompoknya bertanggung jawab untuk menjelaskan. 
4) Tahap selanjutnya, tanggapan dari masing-masing kelompok.

5) Guru memberikan tanggapan dan penegasan tentang materi yang dibahas.

6) Tahap tes hasil belajar

Dilakukan $1 \mathrm{x}$ tes setelah pertemuan, tes dikerjakan secara inividu mandiri. Tes uraian dikerjakan selama 45 menit. Hasil tes digunakan untuk mengetahui apakah ada peningkatan siswa pada pemahaman mata pelajaran PPKn.

2. Pelaksanaan kegiatan yang dilakukan dalam tahap ini adalah melaksanakan skenario pembelajaran kooperatif Model Two Stay Two Stray yang telah direncanakan.

3. Observasi

Pada tahap ini dilakukan observasi terhadap pelaksanaan tindakan dengan menggunakan lembar observasi.

4. Refleksi

Hasil yang didapat dalam tahap observasi dikumpulkan serta dianalisis. pada tahap ini, pengajar dapat merefleksi diri berdasarkan hasil observasi dan diskusi untuk mengkaji apakah tindakan yang telah dilakukan dapat meningkatkan pemahaman siswa pada mata pelajaran PPKn.

\section{Teknik Pengumpulan Data}

Teknik pengumpulan data yang digunakan dalam penelitian tindakan kelas ini adalah:

1. Pedoman observasi aktivitas siswa yang digunakan untuk mengecek kegiatan siswa selama proses belajar mengajar.

2. Lembaran tes untuk melihat hasil belajar siswa

3. Pedoman observasi aktivitas guru yang digunakan untuk mengecek kegiatan guru selama proses belajar mengajar apakah sudah melaksanakan model Two Stay Two Stray dengan baik.

\section{Teknik Analisis Data}

Setelah data terkumpul, data - data ini dianalisa secara kualitatif. Tingkat aktivitas siswa yang semula berupa skor atau nilai hanya merupakan langkah awal, data kualitatif tersebut harus dirubah menjadi data kualitatif dengan memberikan predikat yang menunjukan pernyataan ukuran kualitas (Suharsimi, 2008:351).

Oleh karena itu data hasil penelitian yang berupa bilangan harus dirubah menjadi sebuah predikat yaitu: amat baik, baik, cukup, dan kurang. Nilai aktivitas kelompok dapat dihitung dengan rumus:

$$
\mathrm{N}=\frac{\text { Skor perolehan/ Total Skor }}{\text { Total Skor }} \times 100
$$

Tingkat aktivitas guru juga dianalisis dengan rumus ini. Aktivitas siswa dan guru dikonversikan menjadi predikat aktivitas guru dan siswa sebagai berikut (Tabel 2).

Tabel 2. Koversi Nilai Menjadi Predikat

\begin{tabular}{cc}
\hline Rentang Nilai & Predikat \\
\hline $90-100$ & Amat Baik \\
\hline $76-89$ & Baik \\
\hline $60-75$ & Cukup \\
\hline $0-59$ & Kurang \\
\hline
\end{tabular}

Tingkat hasil belajar siswa dianalisis dengan melihat hasil kuis siswa dan membandingkan hasil belajar siswa pada saat tidak menggunakan model Two Stay Two Stray dengan hasil belajar siswa dengan menggunakan model Two Stay Two Stray.

\section{Indikator Keberhasilan}

Indikator keberhasilan dalam penelitian ini adalah:

1. Aktivitas siswa mendapatkan minimal predikat baik

2. Hasil belajar siswa mencapai kriteria ketuntasan minimal (KKM) yaitu 75 minimal $70 \%$ siswa.

\section{PENELITIAN DAN PEMBAHASAN}

\section{Hasil Penelitian}

1. Hasil Siklus I
a. Tahap Perencanaan (Planning) 
Tahap ini meliputi persiapan awal guru dalam menyiapkan perangkat pembelajaran serta alat dan bahan yang diperlukan dalam kegiatan pembelajaran yaitu berupa: Penyusunan RPP, Penyusunan LKS, Pembuatan Instrumen penilaian, Pembuatan lembar pengamatan aktivitas guru dan siswa serta Pembuatan lembar catatan lapangan

b. Tahap pelaksanaan tindakan (Action) Tahap ini merupakan pelaksanaan pembelajaran yang menerapkan model pembelajaran Two Stay Two Stray, yakni:

Pertemuan 1

(1) Kegiatan pra PBM

- Guru menyiapkan bahan ajaran sesuai dengan kompetensi dasar yang akan dibahas

- Guru mencek kehadiran siswa

- Guru menyiapkan lembaran LKK (Lembar Kerja Kelompok)

(2) Kegiatan Awal

- Guru menjelaskan tentang SK dan KD yang akan dibahas

- Guru menyiapkan tentang pengetahuan dasar tentang sistem pemerintahan (Makna sistem pemerintahan dan Sistem pemerintahan Parlementer)

- Guru membagi kelompok siswa menjadi 3 kelompok dengan anggota dua kelompok 6 orang dan satu kelompok 5 orang.

(3) Kegiatan Inti.

- Siswa melakukan diskusi dalam kelompoknya tentang materi yang menjadi tugas kelompoknya.

- Guru membimbing siswa dalam berdiskusi.

- Siswa yang bertugas sebagai tamu mencari informasi tentang materi lain kekelompok yang lain (15 menit per kelompok).
- Siswa yang bertugas tinggal dikelompoknya membagikan hasil kerja kelompoknya kepada tamu yang datang (15 menit perkelompok).

- Sisiwa yang bertugas sebagai tamu kembali kekelompoknya dan melaporkan informasi yang diperolehnya dari kelompok lain (15 menit).

- Secara acak, perwakilan masing-masing kelompok diminta untuk menyampaikan materi yang telah didapatkan (15 menit)

- Bagian itu dinilai berdasarkan alat penilaian yang telah disediakan dimana hasil penilaian dijadikan nilai kelompok

- Siswa memperoleh kuis individu yang mnecakup semua aspek.

(4) Kegiatan Akhir.

- Penghitungan skor kelompok

- Guru memberikan reward pada kelompok yang berhasil dengan nilai yang baik dan memotivasi kelompok yang masih dibawah ketuntasan minimal.

Pertemuan 2

(1) Kegiatan pra PBM

- Guru menyiapkan bahan ajaran sesuai dengan kompetensi dasar yang akan dibahas

- Guru mencek kehadiran siswa

- Guru menyiapkan lembaran LKK (Lembar Kerja Kelompok)

(2) Kegiatan Awal

- Guru menjelaskan tentang SK dan KD yang akan dibahas

- Guru menyiapkan tentang pengetahuan macam-macam kekuasaan Negara (Konsep pembagian kekuasaan di Indonesia dan Sistem pembagian kekuasaan 
pemerintahan Republik Indonesia)

- Guru membagi kelompok siswa menjadi 3 kelompok dengan anggota dua kelompok 6 orang dan satu kelompok 5 orang.

(3) Kegiatan Inti.

- Siswa melakukan diskusi dalam kelompoknya tentang materi yang menjadi tugas kelompoknya.

- Guru membimbing siswa dalam berdiskusi.

- isiwa yang bertugas sebagai tamu mencari informasi tentang materi lain kekelompok yang lain (15 menit per kelompok)

- Siswa yang bertugas tinggal dikelompoknya membagikan hasil kerja kelompoknya kepada tamu yang datang (15 menit perkelompok)

- Siswa yang bertugas sebagai tamu kembali kekelompoknya dan melaporkan informasi yang diperolehnya dari kelompok lain (15 menit)

- Secara acak, perwakilan masing-masing kelompok diminta untuk menyampaikan materi yang telah didapatkan (15 menit)

- Bagian itu dinilai berdasarkan alat penilaian yang telah disediakan dimana hasil penilaian dijadikan nilai kelompok

- Siswa memperoleh kuis individu yang mnecakup semua aspek.

(4) Kegiatan Akhir.

- Penghitungan skor kelompok

- Guru memberikan reward pada kelompok yang berhasil dengan nilai yang baik dan memotivasi kelompok yang masih dibawah ketuntasan minimal.

c. Tahap Observasi (Observation)
Observasi atau pengamatan dilaksanakan selama penelitian berlangsung, dengan rincian sbagai berikut:

Pertemuan 1

(1) Aktivitas guru

Pada pertemuan pertama kegiatan pembelajaran berjalan cukup lancar. Namun ada beberapa kegiatan dalam lembar observasi guru yang belum dilakukan, yaitu pemberian motivasi kepada siswa dan pengaitan materi dengan pengetahuan yang relevan. Berikut ini tabel 3 hasil observasi aktivitas guru pada siklus I pertemuan 1 .

Tabel 3. Aktivitas Guru pada Siklus I

\begin{tabular}{ccc}
\hline Pertemuan & $\begin{array}{c}\text { Skor hasil } \\
\text { pengamatan }\end{array}$ & Kriteria \\
\hline 1 & 64 & Cukup \\
\hline
\end{tabular}

(2) Aktivitas siswa

Selama proses belajar tidak semua siswa terlibat langsung, masih banyak siswa yang belum aktif. Siswa masih belum terbiasa dengan model pembelajaran Two Stay Two Stray sehingga siswa merasa bingung akibatnya proses pembelajaran belum maksimal. Terlihat ada siswa yang mengerjakan tugas pelajaran lain. Aktivitas siswa perkelompok dapat dilihat pada tabel 4 berikut.

Tabel 4. Aktivitas kelompok siswa pada siklus I pertemuan 1

\begin{tabular}{ccc}
\hline Kelompok & $\begin{array}{c}\text { Nilai } \\
\text { kelompok }\end{array}$ & Kriteria \\
\hline Nusa & 68,75 & Kurang \\
\hline Bangsa & 65,10 & Cukup \\
\hline Bahasa & 58,75 & Kurang \\
\hline
\end{tabular}

Pertemuan 2

(1) Hasil Belajar Siswa

Hasil belajar siswa pada siklus I

diukur dengan memberikan

evaluasi dengan hasil rata-rata 
63,5 pada pertemuan 1 dan ratarata 74,71 pada pertemuan kedua.

(2) Aktivitas Guru

Pada pertemuan kedua proses belajar mengajar berjalan lancar, aktivitas guru mulai meningkat, namun masih ada aspek yang dilakukan dengan kurang baik. Aktivitas guru pada pertemuan 2 dapat dilihat pada tabel 5 berikut:

Tabel 5. Aktivitas Guru pada siklus I

\begin{tabular}{ccc}
\hline Pertemuan & $\begin{array}{c}\text { Skor hasil } \\
\text { pengamatan }\end{array}$ & Kriteria \\
\hline 2 & 68 & Cukup \\
\hline
\end{tabular}

(3) Aktivitas siswa

Pada proses belajar mengajar pada pertemuan 2 aktivitas siswa meningkat dibandingkan dengan pertemuan 1. Hal ini karena siswa sudah mulai terbiasa dengan model pembelajaran yang diterapkan. Semua siswa sudah fokus pada diskusi kelompok dan bertamu ke kelompok lain. Tidak ada lagi siswa yang mengerjakan pekerjaan lain. Namun beberapa siswa masih malu untuk bertanya maupun mengemukakan pendapatnya. Aktivitas kelompok siswa pada pertemuan 2 dapat dilihat pada tabel 6 berikut:

Tabel 6. Aktivitas kelompok siswa pada siklus I pertemuan 2

\begin{tabular}{ccc}
\hline Kelompok & $\begin{array}{c}\text { Nilai } \\
\text { kelompok }\end{array}$ & Kriteria \\
\hline Nusa & 61,98 & Cukup \\
\hline Bangsa & 75,42 & Baik \\
\hline Bahasa & 62,19 & Cukup \\
\hline
\end{tabular}

2. Hasil Siklus II

a. Tahap Perencanaan ( Planning )

Tahap ini meliputi persiapan awal guru dalam menyiapkan perangkat pembelajaran serta alat dan bahan yang diperlukan dalam kegiatan pembelajaran yaitu berupa:

(1) Penyusunan RPP

(2) Penyusunan LKS
(3) Pembuatan Instrumen penilaian (Pretes dan Postes)

(4) Pembuatan lembar pengamatan aktivitas guru dan siswa

(5) Pembuatan lembar catatan lapangan

b. Tahap pelaksanaan tindakan (Action) Tahap ini merupakan pelaksanaan pembelajaran yang menerapkan model pembelajaran Two Stay Two Stray, yakni:

Pertemuan 1

(1) Kegiatan pra PBM

- Guru menyiapkan bahan ajaran sesuai dengan kompetensi dasar yang akan dibahas

- Guru mencek kehadiran siswa

- Guru menyiapkan lembaran LKK (Lembar Kerja Kelompok)

(2) Kegiatan Awal

- Guru menjelaskan tentang SK dan KD yang akan dibahas

- Guru menyiapkan tentang pengetahuan dasar tentang sistem pemerintahan (Sistem penyelenggaraan kekuasaan negara di Indonesia dan membandingkan

penyelenggaraan kekuasaan negara dari John Locke dan Montesquie).

- Guru membagi kelompok siswa menjadi 3 kelompok dengan anggota dua kelompok 6 orang dan satu kelompok 5 orang.

(3) Kegiatan Inti.

- Siswa melakukan diskusi dalam kelompoknya tentang materi yang menjadi tugas kelompoknya.

- Guru membimbing siswa dalam berdiskusi.

- Siswa yang bertugas sebagai tamu mencari informasi tentang materi lain kekelompok yang lain (15 Menit per kelompok)

- Siswa yang bertugas tinggal dikelompoknya membagikan 
hasil kerja kelompoknya kepada tamu yang datang (15 Menit perkelompok)

- Siswa yang bertugas sebagai tamu kembali kekelompoknya dan melaporkan informasi yang diperolehnya dari kelompok lain (15 Menit)

- Secara acak, perwakilan masing-masing kelompok diminta untuk menyampaikan materi yang telah didapatkan (15 Menit)

- Bagian itu dinilai berdasarkan alat penilaian yang telah disediakan dimana hasil penilaian dijadikan nilai kelompok

- Siswa memperoleh kuis individu yang mnecakup semua aspek.

(4) Kegiatan Akhir.

- Penghitungan Skor kelompok

- Guru memberikan reward pada kelompok yang berhasil dengan nilai yang baik dan memotivasi kelompok yang masih dibawah ketuntasan minimal.

Pertemuan 2

(1) Kegiatan pra PBM

- Guru menyiapkan bahan ajaran sesuai dengan kompetensi dasar yang akan dibahas

- Guru mencek kehadiran siswa

- Guru menyiapkan lembaran LKK (Lembar Kerja Kelompok)

(2) Kegiatan Awal

- Guru menjelaskan tentang SK dan KD yang akan dibahas

- Guru menyiapkan tentang pengetahuan dasar tentang sistem pemerintahan (Kelebihan dan kelemahan pelaksanaan sistem pemerintahn Indonesia serta perbandingan pelaksanan sistem pemerintahan Indonesia dengan negara lain).
- Guru membagi kelompok siswa menjadi 3 kelompok dengan anggota dua kelompok 6 orang dan satu kelompok 5 orang.

(3) Kegiatan Inti.

- Siswa melakukan diskusi dalam kelompoknya tentang materi yang menjadi tugas kelompoknya.

- Guru membimbing siswa dalam berdiskusi.

- Siswa yang bertugas sebagai tamu mencari informasi tentang materi lain kekelompok yang lain (15 Menit per kelompok)

- Siswa yang bertugas tinggal dikelompoknya membagikan hasil kerja kelompoknya kepada tamu yang datang (15 Menit perkelompok)

- Siswa yang bertugas sebagai tamu kembali kekelompoknya dan melaporkan informasi yang diperolehnya dari kelompok lain (15 Menit)

- Secara acak, perwakilan masing-masing kelompok diminta untuk menyampaikan materi yang telah didapatkan (15 Menit)

- Bagian itu dinilai berdasarkan alat penilaian yang telah disediakan dimana hasil penilaian dijadikan nilai kelompok

- Siswa memperoleh kuis individu yang mnecakup semua aspek.

(4) Kegiatan Akhir

- Penghitungan Skor kelompok

- Guru memberikan reward pada kelompok yang berhasil dengan nilai yang baik dan memotivasi kelompok yang masih dibawah ketuntasan minimal.

c. Tahap Observasi (Observation)

Observasi atau pengamatan dilaksanakan selama penelitian berlangsung. 
Pertemuan 1

(1) Aktivitas guru

Pada pertemuan 1 ini aktivitas guru sudah mulai meningkat, semua kegiatan dalam lembar observasi guru sudah dilakukan dengan baik, namun belum maksimal.. Adapun aktivitas guru dapat dilihat pada tabel 7 berikut:

Tabel 7. Aktivitas Guru pada Siklus

II

\begin{tabular}{ccc}
\hline Pertemuan & $\begin{array}{l}\text { Skor hasil } \\
\text { pengamatan }\end{array}$ & Kriteria \\
\hline 1 & 63 & Baik \\
\hline
\end{tabular}

(2) Aktivitas siswa

Pada pertemuan pertama siklus II ini aktivitas siswa mulai meningkat, hanya ada beberapa orang saja yang masih belum aktif. Siswa mulai berani bertanya. Aktivitas siswa secara kelompok dapat dilihat pada tabel 8 berikut, sedangkan secara individu dapat dilihat pada lampiran perhitungan aktivitas siswa.

Tabel 8. Aktivitas Siswa pada Siklus II Pertemuan 1

\begin{tabular}{ccc}
\hline Kelompok & $\begin{array}{c}\text { Nilai } \\
\text { kelompok }\end{array}$ & Kriteria \\
\hline Nusa & 75,83 & Baik \\
\hline Bangsa & 77,08 & Baik \\
\hline Bahasa & 66,25 & Cukup \\
\hline
\end{tabular}

Pertemuan 2

(1) Hasil Belajar Siswa

Hasil belajar siswa diukur dari hasil pretes dan postes siswa. Ketuntasan ditentukan berdasarkan nilai KKM mata pelajaran PPKn tahun 2016/2017 yaitu 75 . Adapun hasil pretes dan postes individu yaitu $76 \%$ saja yang tuntas, masih ada $24 \%$ yang belum tuntas. Hasil tersebut dapat dilihat pada tabel terlampir.

(2) Aktivitas guru

Pada pertemuan kedua siklus II, aktivitas guru sudah amat baik namun perlu ditingkatkan kemampuan mengkaitkan materi dengan pengetahuan lain yang relevan, perkembangan Iptek, dan kehidupan nyata. Aktivitas guru pertemuan 2 siklus II dapat dilihat pada tabel 9 berikut:

Tabel 9. Aktivitas guru pada siklus II

\begin{tabular}{|c|c|c|}
\hline Pertemuan & $\begin{array}{c}\text { Skor hasil } \\
\text { pengamatan }\end{array}$ & Kriteria \\
\hline 2 & 71 & $\begin{array}{c}\text { Amat } \\
\text { baik }\end{array}$ \\
\hline
\end{tabular}

(3) Aktivitas siswa

Aktivitas siswa pada siklus II pertemuan 2 sudah baik. Siswa tidak malu lagi bertanya dan mengemukakan pendapat, bahkan mereka berebut untuk menjawab pertanyaan dari guru maupun teman. Semua siswa terlihat sudah aktif dan sudah terbiasa dengan pembelajaran model Two Stay Two Stray. Aktivitas siswa pada saat siklus II pertemuan 2 secara kelompok dapat dilihat pada tabel 10 dibawah ini.

Tabel 10. Aktivitas Siswa pada Siklus II Pertemuan 2

\begin{tabular}{ccc}
\hline Kelompok & $\begin{array}{c}\text { Nilai } \\
\text { kelompok }\end{array}$ & Kriteria \\
\hline Nusa & 78,33 & Baik \\
\hline Bangsa & 90,31 & Amat Baik \\
\hline Bahasa & 76,88 & Baik \\
\hline
\end{tabular}

\section{d. Refleksi (Reflection)}

Berdasarkan data-data dan pengamatan observer kegiatan proses belajar mengajar pada siklus I, maka dapat disimpulkan temuan sebagai berikut:

(1) Hasil belajar siswa sudah meningkat dilihat dari hasil postes yang lebih tinggi dari pada hasil pretes, namun hanya $76 \%$ saja yang tuntas, masih ada $24 \%$ yang belum tuntas.

(2) Aktivitas guru masih mempunyai predikat cukup, karena itu perlu ditingkatkan lagi terutama dalam 
pemberian motivasi kepada siswa, dan menghubungkan materi dengan kehidupan seharihari.

(3) Aktivitas siswa sudah mulai meningkat dengan predikat dua kelompok cukup dan satu kelompok baik. Namun dalam siklus I ini hanya sebagian siswa saja yang aktif, masih ada siswa yang belum aktif dan belum terbiasa dengan model pembelajaran Two Stay Two stray.

Dengan adanya hal ini berarti dapat disimpulkan bahwa model Two stay Two stray dapat meningkatkan aktivitas siswa menjadi lebih aktif.

Tabel 11. Perbandingan Hasil Belajar Siswa

\begin{tabular}{cccc}
\hline \multicolumn{2}{c}{ Siklus I } & \multicolumn{2}{c}{ Siklus II } \\
\hline $\begin{array}{c}\text { Pertemu } \\
\text { an 1 }\end{array}$ & $\begin{array}{c}\text { Pertemu } \\
\text { an 2 }\end{array}$ & $\begin{array}{c}\text { Pertemu } \\
\text { an 1 }\end{array}$ & $\begin{array}{c}\text { Pertemu } \\
\text { an 2 }\end{array}$ \\
\hline 63,5 & 74,71 & 65,89 & 78,82 \\
\hline
\end{tabular}

Berdasarkan hasil penelitian tindakan kelas ini Peningkatan hasil belajar melalui penerapan model two stay two stray pada materi penyelenggaraan kekuasaan negara di Kelas XI MIA 1 MAN 1 Banjarmasin tahun 2016/2017 dari 63,5 menjadi 74,71 (siklus I) dan 65,89 menjadi 78,82 (siklus II).

Terdapat peningkatan aktivitas belajar melalui penerapan model two stay two stray pada materi penyelenggaraan kekuasaan negara di Kelas XI MIA 1 MAN 1 Banjarmasin tahun 2016/2017 yaitu $0 \%$ menjadi $76 \%$ pada siklus I dan dari $0 \%$ menjadi $88 \%$ pada siklus II.

\section{Pembahasan}

Hasil penelitian tindakan kelas ini menunjukkan: (1) terdapat peningkatan hasil belajar melalui penerapan model two stay two stray pada materi penyelenggaraan kekuasaan negara di Kelas XI MIA 1 MAN 1 Banjarmasin tahun 2016/2017 dari 63,5 menjadi 74,71 (siklus I) dan 65,89 menjadi 78,82 (siklus II), (2) terdapat peningkatan aktivitas belajar melalui penerapan model two stay two stray pada materi penyelenggaraan kekuasaan negara di Kelas XI MIA 1 MAN 1 Banjarmasin tahun 2016/2017 yaitu $0 \%$ menjadi $76 \%$ pada siklus I dan dari $0 \%$ menjadi $88 \%$ pada siklus II.

Hasil penelitian ini sesuai dengan pendapat Nawawi (2011:100) mengemukakan hasil belajar sebagai keberhasilan murid dalam mempelajari materi pelajaran di sekolah yang dinyatakan dalam bentuk nilai atau skor dari hasil tes mengenai sejumlah pelajaran tertentu.

Menurut Gagne; (Makmun, 2013), perubahan perilaku yang merupakan hasil belajar dapat berbentuk:

a. Informasi verbal; yaitu penguasaan informasi dalam bentuk verbal, baik secara tertulis maupun tulisan, misalnya pemberian nama-nama terhadap suatu benda, definisi, dan sebagainya.

b. Kecakapan intelektual; yaitu keterampilan individu dalam melakukan interaksi dengan lingkungannya dengan menggunakan simbol-simbol, misalnya: penggunaan simbol matematika. Termasuk dalam keterampilan intelektual adalah kecakapan dalam membedakan (discrimination), memahami konsep konkrit, konsep abstrak, aturan dan hukum. Ketrampilan ini sangat dibutuhkan dalam menghadapi pemecahan masalah.

c. Strategi kognitif; kecakapan individu untuk melakukan pengendalian dan pengelolaan keseluruhan aktivitasnya. Dalam konteks proses pembelajaran, strategi kognitif yaitu kemampuan mengendalikan ingatan dan cara-cara berfikir agar terjadi aktivitas yang efektif. Kecakapan intelektual menitikberatkan pada hasil pembelajaran, sedangkan strategi kognitif lebih menekankan pada proses pemikiran. 
d. Sikap; yaitu hasil pembelajaran yang berupa kecakapan individu untuk memilih macam tindakan yang akan dilakukan. Dengan kata lain, sikap adalah keadaan dalam diri individu yang akan memberikan kecenderungan bertindak dalam menghadapi suatu obyek atau peristiwa, di dalamnya terdapat unsur pemikiran, perasaan yang menyertai pemikiran dan kesiapan untuk bertindak.

e. Kecakapan motorik; ialah hasil belajar yang berupa kecakapan pergerakan yang dikontrol oleh otot dan fisik.

Sedangkan menurut Bloom, perubahan perilaku yang terjadi sebagai hasil belajar meliputi perubahan dalam kawasan (domain) kognitif, afektif dan psikomotor, beserta tingkatan aspekaspeknya. Perubahan yang dihasilkan oleh proses belajar bersifat progresif dan akumulatif, mengarah kepada kesempurnaan, misalnya dari tidak mampu menjadi mampu, dari tidak mengerti menjadi mengerti, baik mencakup aspek pengetahuan (cognitive domain), aspek afektif (affective domain) maupun aspek psikomotorik (psychomotoric domain).

Menurut Yulaelawati (2007) dalam dunia pendidikan penilaian merupakan hal yang mutlak dilakukan, dan menelaah halhal pencapaian hasil belajar peserta didik dan penggunaan hasil belajar tersebut untuk memperbaiki cara belajar peserta didik dan perbaikan program pembelajaran. Aktivitas siswa selama proses pembelajaran merupakan salah satu indikator adanya keinginan siswa untuk belajar. Menurut Tim Instruktur PKG sebagaimana dikutip oleh Pujawan (2004:12), siswa dikatakan memiliki keaktifan apabila ditemukan ciri-ciri sebagai berikut:

a. Antusiasme mengikuti pembelajaran ditandai dengan adanya perilaku: (1) memperhatikan penjelasan guru, (2) tidak mengerjakan pekerjaan lain saat mengikuti pembelajaran, (3) spontan bekerja apabila diberi tugas, dan (4) tidak terpengaruh situasi di luar kelas. b. Terjadi interaksi antara siswa dengan guru ditandai dengan adanya peran siswa dalam: (1) bertanya kepada guru, (2) menjawab pertanyaan guru, (3) memanfaatkan guru sebagai narasumber, dan (4) memanfaatkan guru sebagai fasilitator.

c. Terjadi interaksi antara siswa dengan siswa ditandai dengan adanya perilaku: (1) bertanya kepada teman dalam satu kelompok, (2) menjawab pertanyaan teman dalam satu kelompok, (3) bertanya kepada teman dalam kelompok lain, dan (4) menjawab pertanyaan teman dalam kelompok lain.

d. Adanya kerjasama kelompok ditandai dengan perilaku: (1) membantu teman dalam kelompok yang menjumpai masalah, (2) meminta bantuan kepada teman, jika mengalami masalah, (3) mencocokkan jawaban/konsepsinya dalam satu kelompok, dan (3) adanya pembagian tugas dalam kelompok.

e. Aktivitas siswa dalam kelompok ditandai dengan adanya peran siswa dalam: (1) mengemukakan pendapat, (2) menanggapi pertanyaan/pendapat teman sejawat, (3) mengerjakan tugas kelompok, menjelaskan pendapat/pekerjaannya.

f. Partisipasi siswa dalam menyimpulkan materi pelajaran dapat dilihat dengan adanya perilaku siswa: (1) mengacungkan tangan untuk ikut menyimpulkan, (2) merespon pernyataan/simpulan temannya, (3) menyempurnakan simpulan yang dikemukakan oleh temannya, dan (4) menghargai pendapat temannya.

Berdasarkan teori dan pendapat sejumlah ahli mendukung hasil penelitian ini: (1) terdapat peningkatan hasil belajar melalui penerapan model two stay two stray pada materi penyelenggaraan kekuasaan negara di Kelas XI MIA 1 MAN 1 Banjarmasin tahun 2016/2017 dari 63,5 menjadi 74,71 (siklus I) dan 65,89 menjadi 78,82 (siklus II), (2) terdapat peningkatan aktivitas belajar melalui penerapan model two stay two stray pada 
materi penyelenggaraan kekuasaan negara di Kelas XI MIA 1 MAN 1 Banjarmasin tahun 2016/2017 yaitu 0\% menjadi 76\% pada siklus I dan dari $0 \%$ menjadi $88 \%$ pada siklus II.

\section{PENUTUP}

1. Terdapat peningkatan hasil belajar melalui penerapan model two stay two stray pada materi penyelenggaraan kekuasaan negara di Kelas XI MIA 1 MAN 1 Banjarmasin tahun 2016/2017 dari 63,5 menjadi 74,71 (siklus I) dan 65,89 menjadi 78,82 (siklus II).

2. Terdapat peningkatan aktivitas belajar melalui penerapan model two stay two stray pada materi penyelenggaraan kekuasaan negara di Kelas XI MIA 1 MAN 1 Banjarmasin tahun 2016/2017 yaitu $0 \%$ menjadi $76 \%$ pada siklus I dan dari $0 \%$ menjadi $88 \%$ pada siklus II.

\section{DAFTAR PUSTAKA}

Arikunto,S. 2008. Manajemen Penelitian. PT Asdi Maha Satya: Jakarta.

Asniah. 2013. Peningkatan pemahaman dan kemampuan memecahkan masalah tentang pengelolaan sampah melalui model problem Based Learning pada siswa kelas XI Ak 2 SMK Negeri 1 Tanjung Tahun Pelajaran 2013/2014. Yayasan Adaro Bangun Negeri : Tanjung

Mulyana, E. 2007. Kurikulum Tingkat Satuan Pendidikan. PT Remaja Rosda Karya: Bandung

Yulaelawati, E. 2007. Kurikulum dan Pembelajaran. Pakar Raya: Jakarta. 